\title{
Declaración de Lisboa. Las relaciones entre las facultades de medicina y los sistemas sanitarios en 2007
}

\author{
J. Viñas Salas a , D. Gordon ${ }^{\text {b }}$
}

En la Asamblea General de la Asociación de Facultades de Medicina Europeas (AMSE) que tuvo lugar en Lisboa en junio de 2007 se aprobó la siguiente declaración, para que se tenga en cuenta por los responsables académicos y políticos de los distintos países europeos. Creemos de interés dar a conocer esta declaración y que Educación Médica puede contribuir a su difusión:

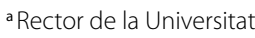
de Lleida.

b Presidente de la Asociación de Facultades de Medicina Europeas (AMSE).

E-mail

bustia@rectorat.udl.es
}

La AMSE reconoce que hay un conjunto de aspectos comunes en Europa relativos a las relaciones entre las facultades de medicina y los sistemas sanitarios en los que están inmersos.

Es esencial trabajar conjuntamente entre las facultades de medicina y los hospitales universitarios, lo que implica un continuo diálogo entre decanos y ejecutivos de los hospitales. Se requiere un liderazgo claro del clínico y del clínico académico en los hospitales universitarios.

Las tensiones identificadas entre las facultades de medicina y los hospitales universitarios incluyen diferencias en el marco temporal: un hospital debe conseguir sus fines, el diagnóstico y tratamiento deben hacerse en horas, días o semanas según se requiera; en cambio, una facultad de medicina tiene una perspectiva de años o décadas; educa a los estudiantes para una práctica clínica de por vida y apoya la investigación, cuya importancia puede no demostrarse en muchos años. Los retos financieros son importantes: el presupuesto del hospital es siempre mucho mayor que el de la facultad de medicina. Hay problemas entre las instituciones causados por la falta de comunicación sobre la política entre los ministerios de salud y educación o equivalentes.

Las facultades de medicina deben estrechar sus lazos con todas las organizaciones asociadas en el sistema sanitario en el cual operan, teniendo en cuenta la amplia gama de centros en los que el
The Association of Medical Schools in Europe (AMSE) recognizes that there is a common set of issues across Europe relating to the relationship between Medical Schools and the health systems in which they operate.

Closer working between Medical Schools and University Hospitals is essential, involving dialogue between Deans and Chief Executives. Clear clinical and clinical academic leadership of affiliated hospitals is required.

The tensions identified between Medical Schools and their affiliated hospitals include differences in time frame: a hospital must meets its targets, where diagnosis and treatment must be made in hours, days or weeks as required; a Medical School has a perspective of years and decades, educating students for a lifetime of evolving clinical practice, and supporting research that may not demonstrate its significance for many years. Financial challenges are important: the budget of the hospital is always much greater than that of the Medical School. There are problems for institutions caused by the lack of communication over policy between Ministries for Health and for Education, or equivalent.

Medical Schools must strive to form close ties with all affiliated organizations in the health care system in which they operate, appreciating the wide range of settings in which the student must train, in order to gain the diversity of experience 
alumno debe formarse para lograr la diversidad de la experiencia necesaria para convertirse en un médico completo y competente.

La experiencia y entrenamiento que los estudiantes adquieren en los centros de asistencia primaria les permite desarrollar una comprensión de todo el espectro de las enfermedades que se ven en la comunidad, complementando su experiencia en los casos especializados tratados en los hospitales universitarios. Gracias a su vinculación con la facultad de medicina, los centros de asistencia primaria y otras organizaciones ganan en prestigio y en potencial para incrementar el volumen de pacientes. Los médicos mismos ganan en oportunidades para continuar su desarrollo profesional. Tales incentivos pueden desarrollarse en la práctica médica generalista por las facultades de medicina, buscando establecer redes entre enseñanza e investigación en medicina primaria. El desarrollo de relaciones entre centros de asistencia primaria, secundaria, terciaria y la facultad de medicina benefician a la comunidad en la cual se insertan estas organizaciones, y facilitan las inversiones internas en investigación y desarrollo, y así se produce un incremento en el bienestar, riqueza y, por ende, en la salud de la población local.

La enseñanza y la investigación en los centros de asistencia primaria y en hospitales universitarios deben tenerse como los componentes esenciales de la educación médica: los dos lados complementarios de la misma moneda.

Las facultades de medicina deben reconocer las necesidades de aprendizaje del médico del siglo XxI y planificar de acuerdo con ellas para proveerle las habilidades que permitan a estos profesionales de la salud adaptarse a los patrones cambiantes de las enfermedades, a la provisión de atención sanitaria, teniendo en cuenta las expectativas de los pacientes, y así prepararles para los desafíos de la atención sanitaria del futuro.

Los mismos estudiantes están cambiando, no sólo en lo referente a su habilidad tecnológica en la entrada a la facultad de medicina, sino también por lo que se refiere a sus actitudes y valores. Los modelos del aprendizaje médico deben reconocerlo e intentar enjaezar tales progresos.

La AMSE ofrece todo su apoyo a un sistema independiente de acreditación y de la garantía de calidad de la educación médica en todos los espacios docentes, incluyendo facultades de medicina, hospitales docentes y otros centros de salud, así como a los esfuerzos para elaborar estándares de la necessary to develop as a well-rounded, competent doctor.

The provision of experience and training for students in Primary Care settings allows them to develop an understanding of the full spectrum of disease seen in the community, complementing experience from the specialized cases treated in a tertiary hospital setting. Through affiliation with a Medical School, Primary Care practices, and other organizations, gain in prestige and a potential increase in patient volume. Practitioners themselves gain opportunities for continuing professional development. Such incentives could be outlined to General Practices by Medical Schools seeking to establish teaching and research networks in Primary healthcare. The development of relationships between Primary, Secondary and Tertiary centers and the Medical School, benefits the community in which these organizations are based, leading to inward investment in research and development and so an increase in the wealth, and ultimately health, of the local population.

Teaching and research in community settings and within University Hospitals should be seen as the essential components of medical education: the two complementary sides of the same coin.

Medical Schools must recognize and plan for the training needs of the 21st Century doctor, providing the skills to allow these healthcare professionals to adapt to changing patterns of disease, of healthcare provision, evolving patient expectations, and so preparing them for future healthcare challenges.

Students themselves are changing, not only in relation to their technological proficiency on entrance to Medical School but also in respect of their attitudes and values. Models of medical training should recognize this and seek to harness such developments.

AMSE is fully supportive of an independent system of accreditation and quality assurance of medical education in all settings, including medical schools, teaching hospitals and other healthcare settings, and of efforts to drive up standards of medical education. AMSE, with the World Federation for Medical Education (WFME), is to build on success in leading the Quality Assurance taskforce under MEDINE 1, by taking a lead in MEDINE 2, and will further explore issues relating to Quality Assurance at its Annual Conference in Barcelona, 2008.

AMSE can act as a vehicle through which best practice across Europe, and more widely, can be 
educación médica. La AMSE, junto con la Federación Mundial para la Educación Médica (WFME), acaba de conducir con éxito el grupo de trabajo sobre la garantía de calidad bajo la red MEDINE 1, tomando el relevo en MEDINE 2, y explora nuevos aspectos referentes a la garantía de calidad en su conferencia anual en Barcelona en 2008.

La AMSE puede actuar como vehículo a través del cual se puedan compartir las mejores prácticas a través de Europa y más allá. Al desarrollar relaciones entre los hospitales universitarios y la atención primaria, los siguientes principios pueden ser de utilidad:

- El liderazgo claro de los decanos de las facultades de medicina en lo referente a la estrategia y a la política en el desarrollo de estrategias de enseñanza y otras áreas del interés mutuo, incluyendo la investigación, en las organizaciones afiliadas, tanto en los hospitales asociados como en los centros de asistencia primaria.

- La necesidad de desarrollar un sistema común de metas y de objetivos compartidos con estos centros asociados.

- La implicación obligatoria de los directivos de la facultad de medicina en la contratación del personal sanitario en los proveedores de salud asociados.

- El reconocimiento de que, aunque Europa puede tener mucho que aprender de otros modelos internacionales, por ejemplo, Norteamérica y otras partes del mundo, las facultades de medicina no deben intentar simplemente imponer estos modelos externos en las estructuras europeas, sino desarrollar e implementar los sistemas apropiados para las necesidades locales.

- La eficaz comunicación de alto nivel entre la facultad de medicina y sus centros asociados, con representación cruzada apropiada en sus principales organismos de gobierno.

- El aseguramiento de que los mentores y tutores en todas las organizaciones están bien entrenados y plenamente cualificados, y de que hay un fuerte desarrollo de la calidad y de las funciones de garantía de calidad, así como de la educación y otras actividades. shared. In developing relationships with University Hospitals and Primary Care, the following principles could prove helpful:

- Clear leadership from Medical School Deans in relation to strategy and policy in the development of teaching strategies and other areas of mutual interest, including research, in affiliated organizations, both hospitals and community services.

- The need to develop a common set of goals and objectives in partnership with these affiliated bodies.

- Obligatory involvement of the Medical Faculty in appointments for staff at affiliated healthcare providers.

- Recognising that, although Europe may have much to learn from models internationally, for example in North America and other parts of the world, Medical Schools should not seek simply to impose external models on European structures, but to develop and implement systems that are appropriate for local need.

- Effective high-level communication between the Medical School and its healthcare partners, with appropriate cross-representation on the relevant governing bodies.

- Assuring mentors and tutors in all organizations are well-trained and fully qualified, and that there is strong Quality Development and Quality Assurance of their role, and of education and of other activities. 